\title{
The Biological Properties of Bamboo Growing Soils in Mid-Hill Conditions of HP: A Comparative Study
}

\author{
Yourmila Kumari*, D.R. Bhardwaj, Rishu Sharma, Meera Devi and Garima \\ Dr YS Parmar University of Horticulture and Forestry, Nauni, \\ Solan, Himachal Pradesh, India \\ *Corresponding author
}

\section{A B S T R A C T}

\begin{tabular}{|l|}
\hline Ke y w o r d s \\
$\begin{array}{l}\text { Bamboo, Soil } \\
\text { microorganism carbon } \\
\text { sequestration potential, } \\
\text { Microbial biomass } \\
\text { carbon, Soil respiration }\end{array}$ \\
\hline Article Info \\
\hline $\begin{array}{l}\text { Accepted: } \\
\text { 07 April } 2018 \\
\text { Available Online: } \\
\text { 10 May } 2018\end{array}$ \\
\hline \hline
\end{tabular}

\section{Introduction}

Bamboo is a group of productive evergreen plants belonging to the subfamily Bambusoideae of the grass family Gramineae, with approximately 1500 known species in 87 genera around the world. Bamboo is widespread and important in the subtropical and tropical regions of Asia, Africa and Latin America (Li and Kobayashi 2004; Zhou et al., 2011). India is the second largest producer of bamboo with 32.3 million ton/year in the world next only to China. There are 130 indigenous as well as exotic bamboo species belonging to 23 genera occurring over an area of 10.03 million ha comprising of about 12.7 per cent of India's total forest area (Sharma, 1980; Varmah and Bahadur, 1980; Biswas, 1994). A rich diversity of bamboo species comprising of about 19 genera and 78 species have been reported in North Eastern India which is the important bamboo growing region of India (Hore, 1998). Bamboo plants propagate, grow and regenerate rapidly. Once established, rapid growth and clonal reproduction increase bamboo's ability to compete for light and space by forming dense stands that can be harvested long-term for timber and bamboo shoots (Silveira, 2005). Bamboo's special biological characteristics 
and growth habits enable bamboo forests to serve ecological and environmental functions such as land rehabilitation, water conservation and control of soil erosion (Zhou et al., 2005).

Some studies have investigated biomass structure, dynamics of litter decomposition and nutrient content of bamboo forests in coastal sandy areas (Zheng et al., 2008), but soil enzymatic and microbial activities have only been measured in the soil of a $C$. equisetifolia forest (Chang et al., 2011). Previous research has shown that the practices of intensively managed bamboo plantations have a negative influence on the biological properties of soils (Xu et al., 2008). Soil properties in a Phyllostachys pubescens forest have been studied (Zhang et al., 2010), but evidence of this issue in bamboo forests in plantation ecosystems is scarce. We aimed to assess soil microbial properties under seven bamboo species as a comparative study under plantation ecosystem. We hypothesized that the introduction of bamboo positively affects soil microbial and enzymatic activities. We tested this hypothesis by addressing three scientific questions: (1) do soil microbial count differ among various bamboo species, which vary in the quantity and quality of litter; (2) how do bamboo species influence the structure of soil microbial biomass carbon, and (3) does the introduction of bamboo improve the fertility of sandy soil? To answer these questions, we investigated seven bamboo species in a mid hill zone of HP, India.

A number of frameworks have been produced to provide quantitative estimates of soil quality. Several of these frameworks rate soil quality by assessing key soil functions, each of which is quantified using physical, biochemical and microbial parameters. These systems have shown the potential to differentiate soil quality in areas receiving contrasting agricultural management regimes
(Glover et al., 2000; Reganold et al., 2001). Those rating systems which do include a microbial component focus on biomass-C and $\mathrm{N}$, the value of which for defining the status of microbial processes, and the characteristics of soil microbial communities, is limited. The parameters associated with microbiological activity were sensitive and rapid indicators of effects of soil management, demonstrating their usefulness as indicators of soil quality in the tropics. The present investigation described the biological properties of soil as affected by 7 year plantations of 7 different bamboo species in mid-hill condition of HP to find out the best suitable species for the mid hill condition which ameliorate the soil health and soil improve the soil quality.

\section{Materials and Methods}

The details of the materials used and the methods followed in carrying out the field sampling and laboratory analysis studies have been described as follows:

\section{Description of the experimental study sites}

The field study was conducted in Mid hill condition of Himachal Pradesh i.e. the field of Department of Silviculture and Agroforestry was choosen for the study on Bamboo plantations in which different species of bamboo were taken. Location of field was at $30^{\circ} 51^{\prime} \mathrm{N}$ latitude and $76^{\circ} 11^{\prime}$ 'E longitude and elevation; 1200m amsl at Nauni, Dr YS Parmar University of Horticulture and Forestry, Nauni-Solan, Himachal Pradesh. The experiment was designed as RBD block planting at $5 \times 5$ meter spacing.

\section{Climatic and edaphic factors}

Climatically, the site lies in the sub-tropical belt but is slightly skewed towards the temperate climate and hence is regarded as a transition zone between sub-tropical and 
temperate climate. The area experiences a wide range of temperature with a minimum of $1^{\circ} \mathrm{C}$ in winter to a maximum of $37^{\circ} \mathrm{C}$ with May and June as the hottest months, whereas December and January, the coldest ones. Winters are accompanied by a fair amount of frost which kills large amount of regeneration in the area but snowfall is witnessed rarely. The area receives maximum downpour during the monsoon season.

\section{Analysis of biological properties of soil}

Soil samples were analyzed for biological properties (Microbial count, Microbial activity and Microbial biomass) as per standard procedures (Table 1).

\section{Statistical analysis}

All the data collected for different experiments and field samples during the study were compiled and processed for statistical treatment. The data were analyzed for the mean and standard error. Analysis of Variance (ANOVA) was used to test the significance of difference between treatment means.

\section{Results and Discussion}

Effect of different bamboo species on biological properties of soil

Microbial biomass carbon (mg MB-C/ 100g soil)

Microbial biomass carbon was significantly increased by different bamboo species and soil layers and higher microbial biomass was recorded under treatment $D$. asper, $\mathrm{T}_{1}(167.00$ $\mathrm{mg}$ MB-C $100 \mathrm{~g}^{-1}$ soil) whereas, the lowest microbial biomass-C was recorded with treatment $\mathrm{T}_{7}\left(150.83 \mathrm{mg}\right.$ MB-C100g ${ }^{-1}$ soil) Table 2. Among soil layers the higher microbial biomass was found under $\mathrm{L}_{1}$ (i.e. 0 -

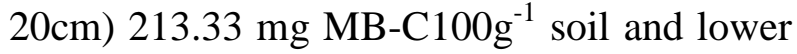

under $\mathrm{L}_{2}$ (i.e. $20-40 \mathrm{~cm}$ ) $105.00 \mathrm{mg}$ MB$\mathrm{C}_{100 \mathrm{~g}^{-1}}$ soil. Higher $\mathrm{MBC}$ was under D. asper in top soil layer it might be due to higher leaf litter production which support the maximum microbial biomass in its rhizosphere, these results are in line with Tariyal (2015) revealed that the soil MBC content decreased with the increasing depth of the soil at all the five study sites and in every month during the study period of two years. Wang et al., (2004) investigated the levels of MBC in the soil profiles of five different vegetation systems including bare area, Bamboo, Chinese fir, Citrus Orchard and Rice field. The MBC level in surface soil for the Bamboo system was higher than those in the other systems. In almost all study sites MBC level was higher during rainy season (Killham 1994; Jiang-shan 2005).

\section{Microbial count $\left(10^{5} \mathrm{cfu}^{-1}\right)$}

\section{Bacterial count}

The bacterial population was significantly influenced by different bamboo species and soil layers (Table 2). Maximum microbial count $\left(227.43 \times 10^{5} \mathrm{cfu} \mathrm{g}^{-1}\right.$ soil $)$ was recorded under $D$. asper $\left(\mathrm{T}_{1}\right)$, while minimum $(210.83$ $\times 10^{5}$ cfu g ${ }^{-1}$ soil) bacterial count with $\mathrm{T}_{7}$. Among soil layers the higher microbial count was found under $L_{1}$ (i.e. $\left.0-20 \mathrm{~cm}\right)(274.33 \times$ $10^{5} \mathrm{cfu} \mathrm{g}^{-1}$ soil) and lower under $\mathrm{L}_{2}$ (i.e. 20$40 \mathrm{~cm})\left(164.72 \times 10^{5} \mathrm{cfu} \mathrm{g}^{-1}\right.$ soil $)$.

\section{Fungal count}

Treatment $\left(\mathrm{T}_{1}\right)$ recorded maximum fungal count $\left(6.12 \times 10^{5} \mathrm{cfu} \mathrm{g}^{-1}\right.$ soil) while minimum $\left(2.53 \times 10^{5} \mathrm{cfu} \mathrm{g}^{-1}\right.$ soil $)$ fungal count was noted in $\mathrm{T}_{7}$ which was statistically at par with $\mathrm{T}_{3}\left(2.74 \times 10^{5} \mathrm{cfu} \mathrm{g}^{-1}\right.$ soil $)$. Among soil layers the higher microbial count was found under $\mathrm{L}_{1}$ (i.e. $0-20 \mathrm{~cm})\left(5.05 \times 10^{5} \mathrm{cfu} \mathrm{g}^{-1}\right.$ soil) and lower under $\mathrm{L}_{2}$ (i.e. $\left.20-40 \mathrm{~cm}\right)\left(3.27 \times 10^{5} \mathrm{cfu}\right.$ $\mathrm{g}^{-1}$ soil). 
Table.1 Methods followed for the analysis of microbial parameters

\section{Microbiological status}

1. Total microbial count $\left(10^{5} \mathrm{cfu} / \mathrm{g}\right) \quad$ Subba Rao (1999)

2. Total microbial biomass carbon Soil fumigation extraction method (Vance et al., 1987)

3. Microbial activity $\mathrm{CO}_{2}$ Evolution Method (Parmer and Schmidt, 1964)

Table.2 Soil biological properties of soil under different bamboo species during the growing season

\begin{tabular}{|c|c|c|c|c|c|c|c|c|}
\hline \multirow[t]{2}{*}{ Treatments } & \multicolumn{3}{|c|}{ Microbial count $\left(10^{5} \mathrm{cfu}^{-1}\right)$} & \multicolumn{4}{|c|}{$\begin{array}{l}\text { Microbial activity } \\
\left(\mathrm{CO}_{2} \text { evolution } \mathrm{g}^{-1}\right)\end{array}$} & \multirow{2}{*}{$\begin{array}{l}\text { Microbial } \\
\text { biomass } \quad \mathrm{Mg} \\
\mathrm{MBC} / 100 \mathrm{~g}\end{array}$} \\
\hline & Bacteria & Actinomycetes & Fungi & $24 \mathrm{hrs}$ & 48hrs & $72 \mathrm{hrs}$ & 96hrs & \\
\hline $\mathbf{T}_{1}$ & 227.43 & 15.35 & 6.12 & 0.24 & 0.34 & 0.21 & 0.19 & 167.00 \\
\hline $\mathbf{T}_{2}$ & 225.43 & 14.01 & 5.46 & 0.21 & 0.32 & 0.18 & 0.17 & 164.50 \\
\hline$T_{3}$ & 213.43 & 11.20 & 2.74 & 0.14 & 0.22 & 0.12 & 0.12 & 153.83 \\
\hline $\mathbf{T}_{4}$ & 220.19 & 12.57 & 4.10 & 0.18 & 0.27 & 0.16 & 0.16 & 159.00 \\
\hline $\mathbf{T}_{5}$ & 223.13 & 13.42 & 4.71 & 0.18 & 0.31 & 0.17 & 0.17 & 161.83 \\
\hline$T_{6}$ & 216.22 & 11.64 & 3.45 & 0.14 & 0.25 & 0.22 & 0.14 & 157.17 \\
\hline $\mathbf{T}_{7}$ & 210.83 & 10.20 & 2.53 & 0.11 & 0.20 & 0.16 & 0.10 & 150.83 \\
\hline Se & 0.38 & 0.24 & 0.12 & 0.01 & 0.01 & 0.05 & 0.006 & 0.45 \\
\hline CD at $5 \%$ & 0.79 & 0.49 & 0.25 & 0.01 & 0.01 & 0.11 & 0.013 & 0.92 \\
\hline \multicolumn{9}{|l|}{ Soil layers } \\
\hline $\mathbf{L}_{1}$ & 274.33 & 16.73 & 5.05 & 0.24 & 0.34 & 0.20 & 0.20 & 213.33 \\
\hline $\mathbf{L}_{2}$ & 164.72 & 8.52 & 3.27 & 0.10 & 0.21 & 0.14 & 0.09 & 105.00 \\
\hline SE & 0.21 & 0.13 & 0.07 & 0.00 & 0.00 & 0.03 & 0.003 & 0.24 \\
\hline CD 5\% & 0.42 & 0.26 & 0.13 & 0.01 & 0.01 & 0.06 & 0.007 & 0.49 \\
\hline
\end{tabular}

Fig.1 Microbial activity as influenced by different treatments (bamboo species)

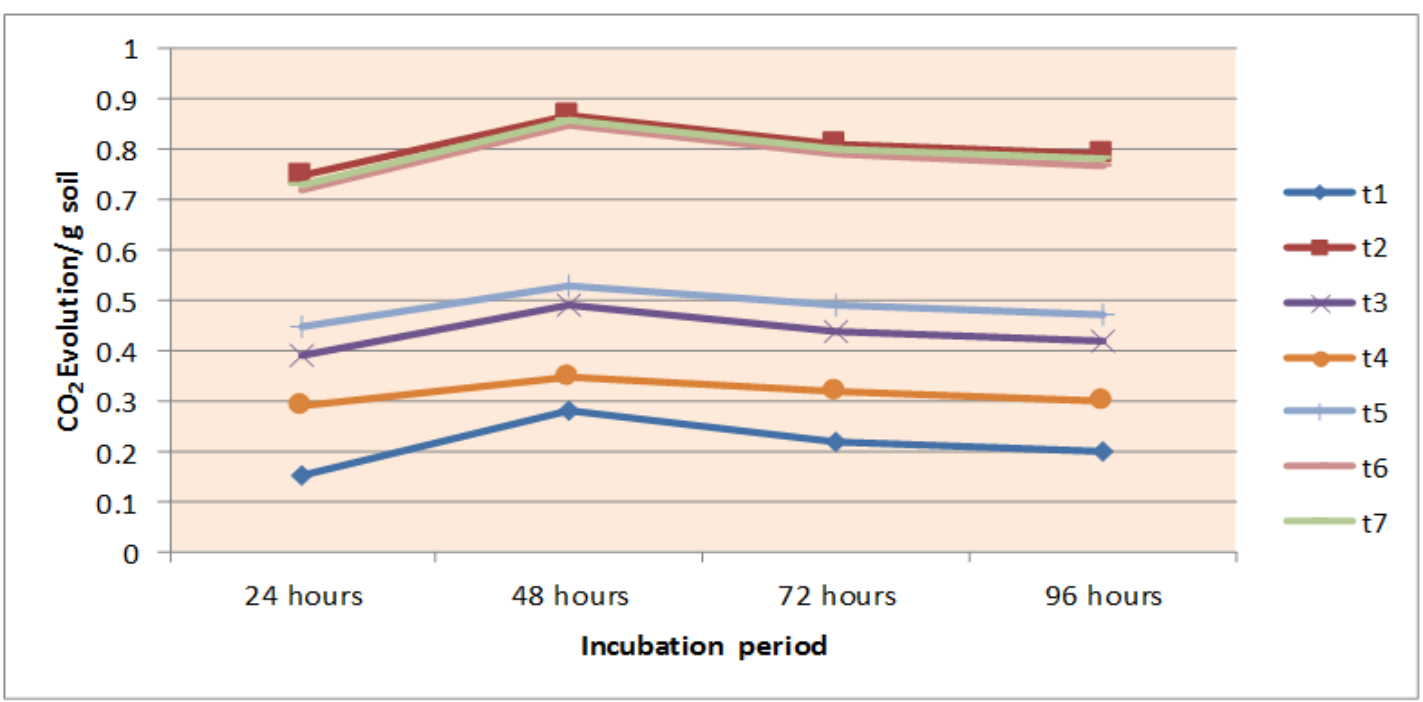




\section{Actinomycetes count}

Soil under D. asper $\left(\mathrm{T}_{1}\right)$ recorded higher actinomycetes count $\left(15.35 \times 10^{5} \mathrm{cfu} \mathrm{g}^{-1}\right.$ soil $)$, while lower $\left(10.20 \times 10^{5}\right.$ cfu $\mathrm{g}^{-1}$ soil $)$ actinomycetes count was noted in $\mathrm{T}_{7}$. Among soil layers the higher microbial count was found under $\mathrm{L}_{1}$ (i.e. $\left.0-20 \mathrm{~cm}\right)\left(16.73 \times 10^{5} \mathrm{cfu} \mathrm{g}^{-1}\right.$ soil $)$ and lower under $\mathrm{L}_{2}$ (i.e. $\left.20-40 \mathrm{~cm}\right)\left(8.52 \times 10^{5}\right.$ cfu $\mathrm{g}^{-1}$ soil). The soil harbour a dynamic population of microorganisms, their abundance in rhizosphere gives an indication of their possible role in decomposition of organic matter, fixation of atmospheric nitrogen, phosphate solubilization, transformations of nutrient elements, etc. The higher organic matter and atmospheric nitrogen registered a significant increase in total microbial population. These results are in conformation with those of Selvi et al., (2004) and Qureshi et al., (2005).

\section{Microbial activity $\left(\mathrm{CO}_{2}\right.$ evolution $\mathrm{g}^{-1}$ soil $)$}

The rate of $\mathrm{CO}_{2}$ evolution in treatment comprising different species of bamboo increased up to 48 hour and then followed a sudden decrease and remained in decreasing trend with increase in incubation period (Figure 1). However, the rate of $\mathrm{CO}_{2}$ evolution was higher under treatment $D$. asper $\mathrm{T}_{1}$ after 48 hours and lower was recorded with $\mathrm{T}_{7}$ after 24 hrs of incubation period it might be due to higher leaf litter production under this species as compared to other species under study.

At the surface layer there was a noticeable increase in soil respiration as compared to subsurface soil. Labile carbon compounds in the litter are utilized by the microbes and resulted in the release of $\mathrm{CO}_{2}$ as soil respiration activity (Brady, 1990). Among soil depths the surface layer the graph shows a significant difference in soil respiration activity in study site between both depths. The soil respiration is the direct function of microbial populations and carbon availability in the soil (Myrold, 1987). Overall the subsurface layer showed lesser soil respiration activity as compared to the surface layer in the study sites (Shrestha et al., 2008). The surface layer of the study sites are richer in carbon and nitrogen content in comparison to the subsurface layer thus higher values of soil respiration were observed in the surface layer in all the sites.

The MBC in the entire soil microbial population treated as an entity. The soil MBC is a source of nutrients and used to predict the effects of ecosystem perturbations. This is why microbial indicators have been used as reliable tools to characterize soil quality with respect to land use and soil management. The results showed that the population levels of soil microorganisms were generally different among the different species types. The total amounts of microorganisms, microbial count and activity under the $D$. asper were higher than under the other species in bamboo plantation ecosystem. Among the soil depths the top layer showed higher microbial parameter and lower values in the subsurface layer. The surface layer of the study sites are richer in carbon and nitrogen content in comparison to the subsurface layer thus higher values of microbial parameter were observed in the surface layer. On the basis of the results obtained in the present investigation it may be concluded that choice of species for plantation influences carbon storage and soil biological properties of the plantation ecosystem. The introduction of bamboo plantation may thus be able to improve soil fertility and microbial activity, while increasing tree diversity.

\section{References}

Brady N C. 1990. "The Nature and properties of soils". Macmillan, New York. 621 pp.

Chang E H, Chen C T, Chen T H and Chiu C Y 2011. Soil microbial communities and activity in sand dunes of subtropical coastal forests. Appl. Soil Ecol. 49: 256262

Glover J D, Reganold J P and Andrews P K. 2000. Systematic method for rating soil quality of conventional, organic, and integrated apple orchards in Washington 
state. Agriculture Ecosystems and Environment 80: 29-45.

Jiang-shan Z, Jian-fen G, Guang-shui C and Wei Q. 2005. Soil microbial biomass and its controls. Journal of Forestry Research 16 (4): 327-330.

Killham K. 1994. Soil Ecology [M]. Cambridge: Cambridge University Press.

Li Z H and Kobayashi M. 2004. Plantation future of bamboo in China. J. For. Res. 15: 233-242 .

Myrold D D. 1987. Relationship between microbial biomass nitrogen and nitrogen availability index. Soil Use Manage 7: 189-192.

Qureshi A A, Narayanaswamy G, Chhonkar P K and Balasundaram V R. 2005. Direct and residual effect of phosphate rocks in presence of phosphate solubilizers and FYM on the available $\mathrm{P}$, organic carbon and viable counts of phosphate solubilizers in soil after soybean, mustard and wheat crops. Journal of the Indian Society of Soil Science 53(1): 97-100.

Reganold J P, Glover J D, Andrews P K and Hinman H R. 2001. Sustainability of three apple production systems. Nature 410: 926-930

Selvi D, Santhy P, Dhakshinamoorthy M and Maheshwari M. 2004. Microbial population and biomass in rhizosphere as influenced by continuous intensive cultivation and fertilization in an inceptisol. Journal of the Indian Society of Soil Science 52(3): 254-257.

Sharma B D, Hore D K, Pandey G and Wadhwa B M. 1992. Genetic resources of bamboo plantations. Indian Journal of Forestry 15(1): 44-51.

Shrestha B M and Singh B R. 2008. Soil and vegetation carbon pools in a mountainous watershed of Nepal. Nutr Cycl Agroecosyst 81:179-191.

Silveira M. 2005. A floresta aberta com bambu no sudoeste da Amazônia: padrõese processos em múltiplas escalas $1-153$

Wang E E, Cben Y X, Tian G M 2004. Microbial biomass carbon, nitrogen and phosphorus in the soil profiles of different vegetation covers established for soil rehabilitation in a red soil region of southeastern China [1]. Nutrient Cycling in Agroeeosystems 68: 181-189.

Xu Q, Jiang $\mathrm{P}$ and $\mathrm{Xu}$ Z. 2008. Soil microbial functional diversity under intensively managed bamboo plantations in southern China. J. Soil Sediment 8: 177-183

Zhang C S, Xie G D, Fan S H and Zhen L. 2010. Variation in vegetation structure and soil properties, and the relation between understory plants and environmental variables under different Phyllostachys pubescens forests in Southeastern China. Environment Management 45: 779-792.

Zhou B Z, Fu M Y, Xie J Z, Yang X S and Li Z C. 2005. Ecological functions of bamboo forest: research and application. J. For. Res, 16: 143-147.

Zhou G M, Meng C F, Jiang P K and Xu Q F. 2011. Review of carbon fixation in bamboo forests in china. Bot. Rev. 77: 262- 270 .

\section{How to cite this article:}

Yourmila Kumari, D.R. Bhardwaj, Rishu Sharma, Meera Devi and Garima. 2018. The Biological Properties of Bamboo Growing Soils in Mid-Hill Conditions of HP: A Comparative Study. Int.J.Curr.Microbiol.App.Sci. 7(05): 507-512. doi: https://doi.org/10.20546/ijcmas.2018.705.064 